\title{
Dendritic cell distribution in mycosis fungoides vs. inflammatory dermatosis and other T-cell skin lymphoma
}

\author{
MIRELA CIOPLEA $^{1 *}$, COSTIN CARUNTU $^{2 *}$, SABINA ZURAC ${ }^{1,3}$, ALEXANDRA BASTIAN $^{1,3}$, \\ LIANA STICLARU $^{1}$, ALEXANDRA CIOROIANU ${ }^{1}$, DANIEL BODA ${ }^{4,6}$, GHEORGHITA JUGULETE ${ }^{5,7}$, \\ LUCIANA NICHITA $^{1,3}$ and CRISTIANA POPP ${ }^{1}$ \\ ${ }^{1}$ Department of Pathology, Colentina University Hospital, 020125 Bucharest; ${ }^{2}$ Department of Physiology, \\ ${ }^{3}$ Department of Pathology, ${ }^{4}$ Excellence Center in Dermatology and ${ }^{5}$ Department of Infectious Diseases, \\ 'Carol Davila' University of Medicine and Pharmacy, 050474 Bucharest; ${ }^{6}$ National Institute of Diabetes, \\ Nutrition and Metabolic Diseases 'Prof. Dr. Nicolae Paulescu', 020475 Bucharest; ${ }^{7}$ National Institute of \\ Infectious Diseases ‘Prof. Dr. Matei Bals’, 021105 Bucharest, Romania
}

Received September 10,2018; Accepted January 10, 2019

DOI: $10.3892 / \mathrm{ol} .2019 .10097$

\begin{abstract}
Dendritic cells (DCs) are antigen-presenting cells with an important role in the innate and adaptive immune system. In skin lesions, cutaneous DCs (Langerhans cells, dermal DCs and plasmacytoid DCs) are involved in immune activation in inflammatory benign lesions, as well as in malignant lymphoid proliferations. Density and distribution of DCs in the dermal infiltrate can be helpful to differentiate benign, reactive infiltrate from malignant nature of the lymphoid population. We performed a retrospective study including 149 patients: 35 with mycosis fungoides, 35 with spongiotic dermatitis, 35 with psoriasis, 35 with lupus and 9 with cutaneous T-cell lymphomas (other than mycosis fungoides), diagnosed using histopathological and immunohistochemical stains. Density and distribution of DCs were evaluated using specific markers (CD1a, CD11c and langerin). In all cases, numerous DCs were identified in the dermal infiltrate. Their number was significantly increased in mycosis fungoides and T-cell lymphomas and moderately increased in inflammatory lesions. Variable patterns of distribution were identified such as clusters of DCs with arachnoid extension in mycosis fungoides, nodular pattern in inflammatory lesions and dispersed distribution with peripheric accumulation in T-skin lymphomas. Therefore, immunohistochemical characterization of DC distribution can be an adjuvant tool in differential diagnosis in inflammatory dermatosis and skin lymphomas.
\end{abstract}

Correspondence to: Dr Luciana Nichita, Department of Pathology, Colentina University Hospital, 21 Stefan cel Mare Street, 020125 Bucharest, Romania

E-mail: luciana.nichita@yahoo.com

${ }^{*}$ Contributed equally

Key words: dendritic cells, inflammatory dermatosis, cutaneous $\mathrm{T}$ cells lymphoma

\section{Introduction}

Dendritic cells (DCs) are antigen-presenting cells with an important role in the innate and adaptive immune system. In skin lesions, cutaneous DCs (Langerhans cells, dermal DCs and plasmacytoid DCs) are involved in immune activation in inflammatory benign lesions (psoriasis, lupus erythematosus (LE), spongiotic dermatitis), as well as in malignant lymphoid proliferations (mycosis fungoides, cutaneous T-cell lymphoma). DCs are a modulator of skin immunity, with a significant role in immunological reactions as well as in immune tolerance to various factors, including tumor cells and auto-immune stimuli (1). In antitumor immune defense, DCs are antigen-presenting cells for $\mathrm{CD} 8^{+} \mathrm{T}$-lymphocytes via histocompatibility complex class I (2).

Recent studies have defined DCs as immune regulators of the skin with a key role in various complex reactions such as antitumoral immunity, maintenance of immune homeostasis, modulation of T-cell function, wound healing and interaction with skin grafts and immune evasion of HIV (3-6).

Since DCs are located within the epidermis and dermis as well, their activation intervenes early during the interaction with environmental factors. Their migrating capacity to local lymph nodes is involved in regional and systemic response to skin injuries (5).

From our point of view, the study of DCs in inflammatory and tumoral skin lesions should concern two interconnected aspects: the distribution of DCs and their role in lesional mechanisms.

Their special pattern of distribution in inflammatory dermatitis and skin lymphomas is useful not only to better understand pathophysiologic mechanisms involved in these diseases, but also as an adjuvant tool for diagnosis. In addition, they may play an important role in therapeutical approaches in inflammatory skin diseases $(7,8)$.

Our team previously presented studies concerning DC distribution in cutaneous melanoma (1) as well as in mycosis fungoides vs. inflammatory dermatoses $(9,10)$. This preoccu- 
pation for DCs revealed interesting results that prompted the initiation of this study.

Thus, in melanoma, DCs are especially found in areas of regression, being involved in the immune mechanisms that determine tumor cell destruction. Moreover, DCs have significant patterns of distribution in areas of regression (nodular pattern) compared with areas without regression (predominantly diffuse pattern) $(2,11)$. These data suggest that DCs are active players in melanoma's regression and could be used as therapeutical targets to enhance this natural process of tumor clearance $(2,12)$.

On the other hand, in spongiotic dermatitis, we described a nodular pattern of DC distribution, while in the early stage mycosis fungoides (patch/plaque stage), DCs were distributed in clusters with arachnoid extensions. To the best of our knowledge, this feature is very useful in difficult differential diagnosis of mycosis fungoides vs. spongiotic dermatitis (9).

Different studies describe specific roles of skin DCs in various inflammatory and tumoral conditions.

In psoriasis, a chronic inflammatory skin model type 1 autoimmune disease with a strong interferon- $\gamma$ (IFN- $\gamma$ ) T helper 1 (Th1) signal (13-15), DCs interact with $\mathrm{CD}^{+}{ }^{+} \mathrm{T}$ cells and keratinocytes, controlling the fate of resident memory $\mathrm{T}$ cells and their response to various pro-inflammatory cytokines [as interleukin (IL)-17, IL-1 $\beta$, IL-23] $(3,13)$.

In LE, a chronic autoimmune disease $(16,17)$, DCs (especially the plasmocytoid subtype) have an important role by producing type I IFN (16-18).

In spongiotic dermatitis, DCs initiate the inflammatory process after the ones located in epidermis are activated by environmental allergens (19-21). Also, they have a high affinity for $\operatorname{IgE}$, determining the increase of antigen uptake (5).

In mycosis fungoides, a common cutaneous T-cell lymphoma with dermal infiltrate T cells, DCs have an unclear role in pathogenesis and progression (22). Their number is increased in all stages of the disease, with a greater emphasis on the tumor stage of the disease. They probably enhance tumor progression using the same pathway as regulatory T cells (23).

In cutaneous $\mathrm{T}$-cell lymphoma, a neoplasm of memory inducer T cells (24-26), usually, neoplastic T cells, are mixed with a significantly increased number of Langerhans cells suggesting that the neoplastic process is triggered by DCs (22). In addition, immature DCs facilitate the survival of malignant T cells (27).

\section{Patients and methods}

Patients. We performed a retrospective study including 149 patients: 35 with mycosis fungoides, 35 with spongiotic dermatitis, 35 with psoriasis, 35 with lupus and 9 with cutaneous T-cell lymphomas (other than mycosis fungoides) diagnosed using histopathological and immunohistochemical staining between January 2012 and December 2016 at the Department of Pathology, Colentina University Hospital (Bucharest, Romania). Skin biopsies (incisional or excisional), received for histopathological diagnosis, were also included. All specimens were sampled according to the Pathology Guidelines of Medical Practice (Ministry of Health Regulation no. 1217/September 16, 2010 published in Official Monitor no. 723/October 29, 2010, annex 1), routinely processed for paraffin-embedding. The tissue was fixed in formaldehyde, solution $4 \%$, buffered, $\mathrm{pH} 6.9$, room temperature, $6-8 \mathrm{~h}$. Then, $3 \mu \mathrm{m}$ sections were cut and routinely stained with hematoxylin and eosin (H\&E). All slides were examined by at least two senior pathologists and, in selected cases, immunohistochemical assays were performed for diagnosis. After establishing the diagnosis, 13 samples of mycosis fungoides, psoriasis, LE, spongiotic dermatitis and $\mathrm{T}$ cell lymphoma were included in the research cohort.

This study was approved by the Ethics Committee of Colentina University Hospital (Bucharest, Romania), and written informed consent was obtained from all the patients for the use of their tissue, after diagnosis for experimental purposes.

Mehods. From each case we performed manual tissue multiarray (TMA) blocks. Tissue was extracted from the paraffin blocks and then embedded into recipient blocks, each including 8 samples from 8 patients. From each TMA block $3 \mu \mathrm{m}$ sections were performed using a semi-automatic Leica RM2245 rotary microtome. One slide was used for routine stain $(\mathrm{H} \& \mathrm{E})$ and 10 immunohistochemical slides for CD1a, CD11c and langerin (Table I). As a detection system, we used Polymer Novolink (Leica Biosystems Nussloch $\mathrm{GmbH}$, Nussloch, Germany). Immunohistochemical staining was analyzed using a microscope Olympus CX41 (Olympus, Tokyo, Japan).

Density and distribution of DCs were evaluated by two independent pathologists with expertise in dermatopathology. They estimated both the number of DCs and their pattern of distribution.

All data were registered in a database and statistically analyzed using Microsoft Excel (Microsoft, Redmond, Washington, USA) and IBM SPSS Statistics (version 22.0; IBM Corp., Armonk, NY, USA).

\section{Results}

Histological analysis of DC distribution. Histological examination of all cases identified various patterns of the DC distribution in the examined conditions: Clusters of DCs with arachnoid extension in mycosis fungoides, nodular pattern (Fig. 1) in inflammatory lesions and dispersed distribution with peripheric accumulation and arachnoid in T-skin lymphomas (Fig. 2). In mycosis fungoides and T-cell lymphoma, the number of DCs was increased both in epidermis and malignant infiltrate (Fig. 3) compared with inflammatory lesions, in which the number of DCs was decreased in dermal inflammatory infiltrate while it remained in moderate numbers in epidermis.

In inflammatory lesions, spongiotic dermatitis (Fig. 4), psoriasis (Fig. 5) and LE (Fig. 6), the predominant pattern was the nodular, followed by a dispersed pattern. The density of the DCs was decreased in inflammatory infiltrate compared with neoplastic conditions. The number of DCs in inflammatory lesions was higher in epidermis.

In mycosis fungoides (Fig. 7) and cutaneous T-cell lymphoma (Fig. 8), the predominant pattern was the arachnoid one. In cutaneous T-cell lymphoma, peripheric accumulation of DCs was observed, while an increased number of DCs was displayed in epidermis. 
Table I. Antibodies used for the study.

\begin{tabular}{lccccc}
\hline Primary antibody & Clone & Host & Supplier & Dilution & \multicolumn{1}{c}{ Specificity } \\
\hline CD1a & MTB1 monoclonal & Mouse & Leica Biosystems & $1: 50$ & Human CD1a molecule \\
CD11c & 5D11 monoclonal & Mouse & Leica Biosystems & $1: 100$ & Human CD11c antigen \\
Langerin & 12D6 monoclonal & Mouse & Leica Biosystems & $1: 50$ & Human langerin \\
\hline
\end{tabular}

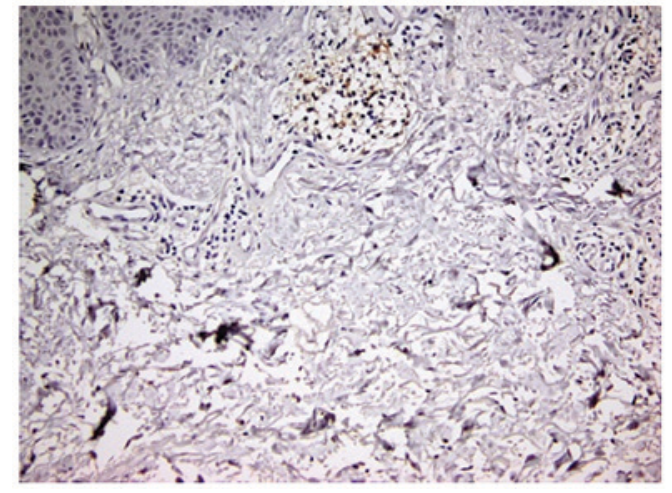

Figure 1. Nodular pattern in inflammatory conditions (x100 magnification).

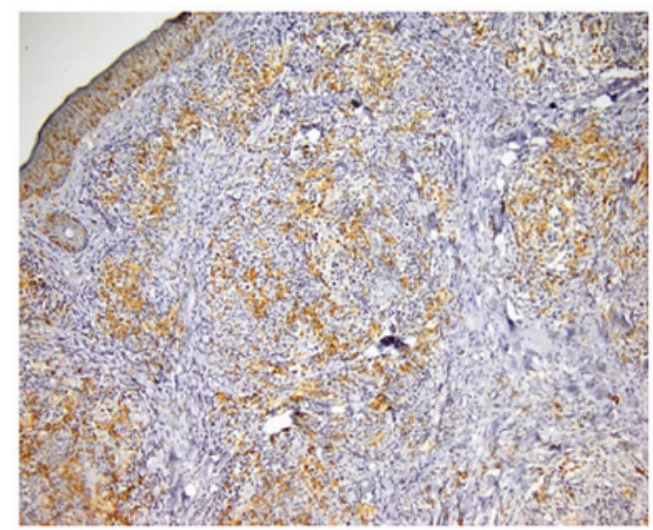

Figure 2. Dispersed distribution with peripheric accumulation pattern in cutaneous T-cell lymphoma (x100 magnification).

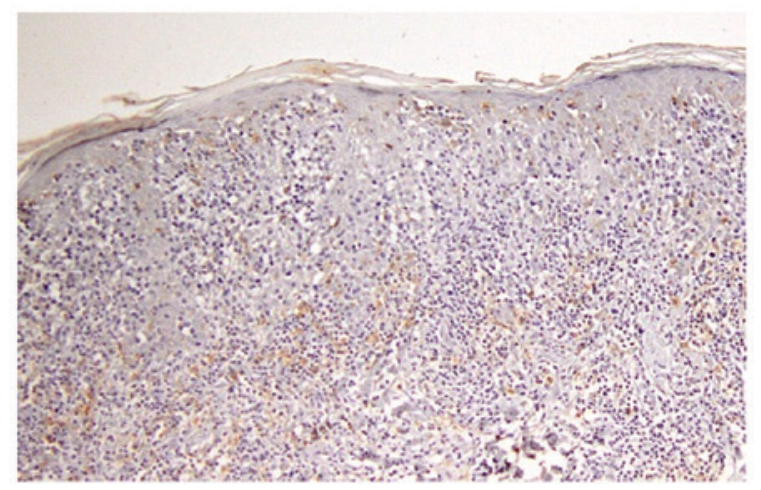

Figure 3. Arachnoid pattern in mycosis fungoides (x100 magnification).

Frequency of DCs. In neoplastic conditions, CD1a, CD11c and langerin-positive DCs were present in a higher number both in epidermis and neoplastic infiltrate (Table II).

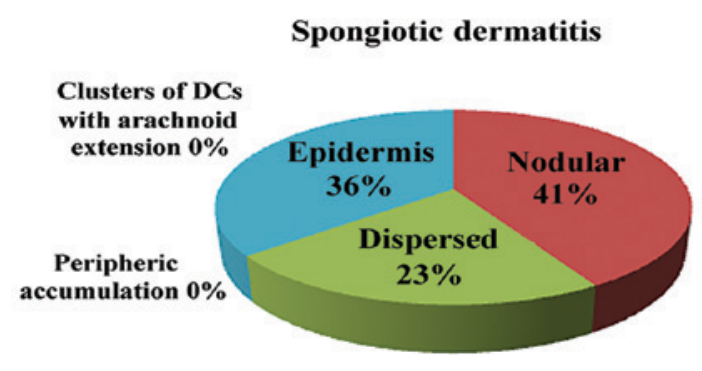

Figure 4. Distribution pattern in spongiotic dermatitis.

\section{Psoriasis}

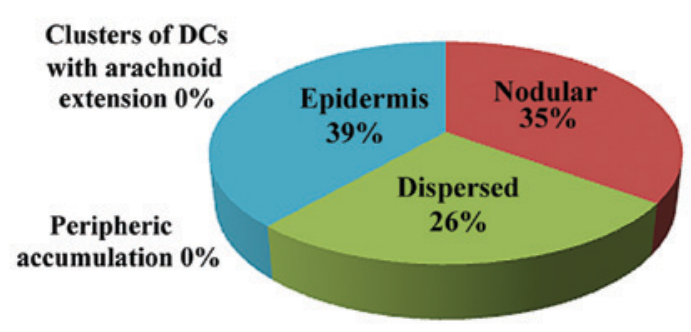

Figure 5. Distribution pattern in psoriasis.

\section{Lupus erythematosus}

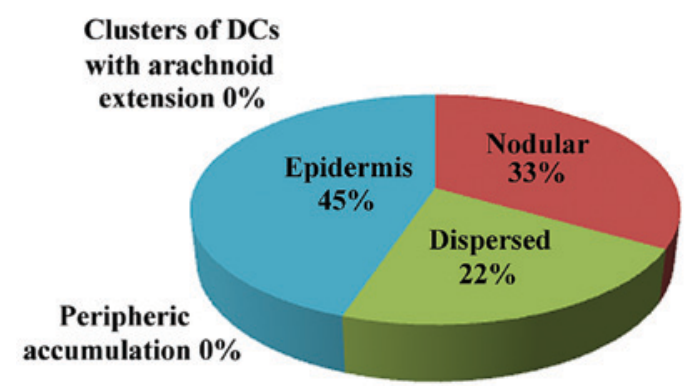

Figure 6. Distribution pattern in LE. LE, lupus erythematosus.

In inflammatory lesions, the frequency of CD1a, CD11c and langerin-positive DCs was different. CD1a-positive DCs were rare in epidermis of the spongiotic dermatitis, psoriasis and frequently in LE. In inflammatory infiltrate, CD1a-positive DCs were rare in spongiotic dermatitis and LE and numerous in psoriasis. CD11c-positive DCs was rare in epidermis of the spongiotic dermatitis and frequent in psoriasis and LE. In inflammatory infiltrate, CD11c-positive DCs were numerous in psoriasis, LE and psoriasis. Langerin-positive DCs were rare in epidermis of the psoriasis, and LE, but they were frequent in spongiotic dermatitis. In inflammatory infiltrate, 
Table II. Frequency of dendritic cells.

\begin{tabular}{|c|c|c|c|c|c|}
\hline Markers & $\begin{array}{l}\text { Mycosis } \\
\text { fungoides }\end{array}$ & $\begin{array}{c}\text { Cutaneous T-cell } \\
\text { lymphoma }\end{array}$ & $\begin{array}{l}\text { Spongiotic } \\
\text { dermatitis }\end{array}$ & Psoriasis & $\begin{array}{c}\text { Lupus } \\
\text { erythematosus }\end{array}$ \\
\hline CD1a & $\begin{array}{l}\text { Numerous DCs CD1a } \\
\text { in neoplastic } \\
\text { infiltrate and } \\
\text { in epidermis }\end{array}$ & $\begin{array}{l}\text { Numerous DCs CD } 1 \mathrm{a}^{+} \\
\text {in neoplastic } \\
\text { infiltrate and } \\
\text { in epidermis }\end{array}$ & $\begin{array}{l}\text { Rare DCs CD } 1 \mathrm{a}^{+} \\
\text {in inflammatory } \\
\text { infiltrate and } \\
\text { in epidermis }\end{array}$ & $\begin{array}{l}\text { Numerous DCs CD1a } \\
\text { in inflammatory } \\
\text { infiltrate and } \\
\text { rare in epidermis }\end{array}$ & $\begin{array}{l}\text { Rare DCs CD1a } \\
\text { in inflammatory } \\
\text { infiltrate and } \\
\text { in epidermis }\end{array}$ \\
\hline CD11c & $\begin{array}{l}\text { Numerous DCs } \\
\text { CD11c-positive in } \\
\text { neoplastic infiltrate } \\
\text { and rare in epidermis }\end{array}$ & $\begin{array}{l}\text { Numerous DCs } \\
\text { CD11c-positive in } \\
\text { neoplastic infiltrate } \\
\text { and in epidermis }\end{array}$ & $\begin{array}{l}\text { Numerous DCs } \\
\text { CD1a-positive } \\
\text { in inflammatory } \\
\text { infiltrate and rare } \\
\text { in epidermis }\end{array}$ & $\begin{array}{l}\text { Numerous DCs } \\
\text { CD1a-positive } \\
\text { in inflammatory } \\
\text { infiltrate and } \\
\text { in epidermis }\end{array}$ & $\begin{array}{l}\text { Numerous CD1a } \\
\text { DC-positive } \\
\text { in inflammatory } \\
\text { infiltrate and } \\
\text { in epidermis }\end{array}$ \\
\hline Langerin & $\begin{array}{l}\text { Numerous DCs } \\
\text { langerin-positive } \\
\text { in neoplastic } \\
\text { infiltrate and } \\
\text { in epidermis }\end{array}$ & $\begin{array}{l}\text { Rare DCs } \\
\text { langerin-positive } \\
\text { in neoplastic infiltrate } \\
\text { and numerous } \\
\text { in epidermis }\end{array}$ & $\begin{array}{l}\text { Rare DCs } \\
\text { langerin-positive } \\
\text { in inflammatory } \\
\text { infiltrate and numerous } \\
\text { in epidermis }\end{array}$ & $\begin{array}{l}\text { Numerous DCs } \\
\text { langerin-positive } \\
\text { in inflammatory } \\
\text { infiltrate and } \\
\text { rare in epidermis }\end{array}$ & $\begin{array}{l}\text { Rare DCs } \\
\text { langerin-positive } \\
\text { in inflammatory } \\
\text { infiltrate and } \\
\text { in epidermis }\end{array}$ \\
\hline
\end{tabular}

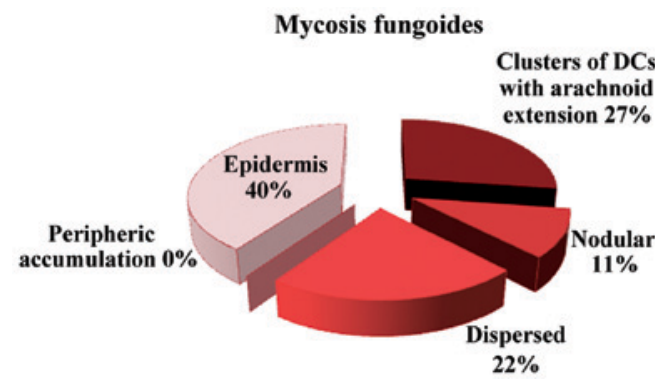

Figure 7. Distribution pattern in mycosis fungoides.

langerin-positive DCs were rare in spongiotic dermatitis and LE, but they were numerous in psoriasis.

\section{Discussion}

Although the role of DCs in various skin diseases has been described by many studies, there are still very few recent studies concerning DC distribution patterns in skin inflammatory conditions and cutaneous malignant T-cell disorders. In our clinic, this is the second study analyzing the distribution patterns classified as arachnoid, diffuse and nodular in inflammatory cutaneous diseases and malignant T-cell conditions and identifying significant differences between distribution of DCs in benign and malignant skin lesions $(1,9)$.

These data are important, in the first place, for diagnosis since sometimes, because of the marked inflammatory infiltrate, differential diagnosis between malignant lymph cell proliferation and inflammatory dermatosis can be difficult. The pattern of distribution of DCs can help to differentiate these disorders, as a supplementary tool to usual histopathological and immunohistochemical features.

In addition, identification of significant differences between DC distribution in these two types of diseases is an indicator of different levels of involvement of DCs in the pathophysiological mechanisms of the disease. In inflammatory dermatoses, DCs have mostly a nodular distribution pattern, while

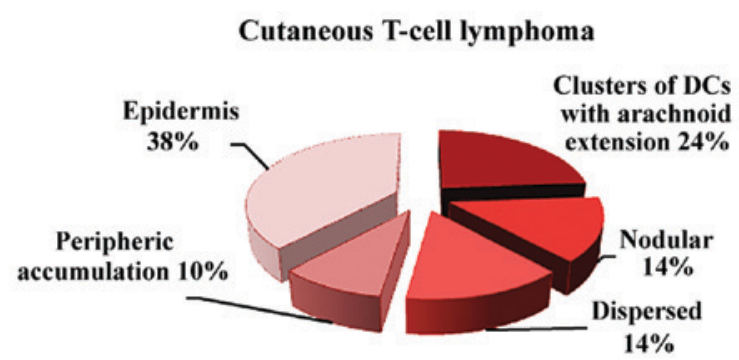

Figure 8. Distribution pattern in cutaneous T-cell lymphoma.

in malignant lymph cell infiltrates, the most frequent pattern is an arachnoid distribution, intermingled with tumoral cells. These data are consistent with the fact that in inflammatory dermatoses, DCs most important role is activation by various antigens with subsequent trigger and modulation of inflammation, while in malignant lymph cell infiltrates, DCs have a more complex role as they are involved not only in triggering the disease, but also in tumor progression and regression.

In conclusion, immunohistochemical characterization of DC distribution can be an adjuvant tool in differential diagnosis in inflammatory dermatosis and skin lymphomas. At the same time, it can be correlated with functional studies explaining the role of skin DCs (local and migrated) in all phases of the disease.

This study identifies significant differences between benign and malignant skin conditions concerning DC distribution and can be integrated in a larger framework of immune interactions between the host and immune as well as tumoral factors involved in skin lesions.

\section{Acknowledgements}

Not applicable.

\section{Funding}

This study is partially supported by Executive Agency for Higher Education, Research, Development and Innovation 
(UEFISCDI; Bucharest, Romania) under the contract no. PN-III-P1-1.2-PCCDI-2017-0341.

\section{Availability of data and materials}

The datasets used and/or analyzed during the current study are available from the corresponding author on reasonable request.

\section{Authors' contributions}

MC, CC and SZ contributed to the conception of this study and performed the preliminary documentation. All authors participated in the design of the study and implemented the research. MC, SZ, CP, LN, LS, AB and AC examined the archives and identified the cases included in the study, examined the slides and collected the pathological information. CC, DB and GJ enrolled patients in the study, performed clinical diagnosis and collected clinical data. All authors participated in the statistical analysis and contributed to the interpretion of the results as well as the writing of the study. All authors reviewed all data and approved the final manuscript.

\section{Ethics approval and consent to participate}

This research abides by the International and National regulations in accordance with the Declaration of Helsinki. It was approved by the Ethics Committee of the Colentina University Hospital (Bucharest, Romania). All patients signed an informed consent before being included in this study.

\section{Patient consent for publication}

Not applicable.

\section{Competing interests}

The authors declare that they have no competing interests.

\section{References}

1. Neagu M, Caruntu C, Constantin C, Boda D, Zurac S, Spandidos DA and Tsatsakis AM: Chemically induced skin carcinogenesis: Updates in experimental models (Review). Oncol Rep 35: 2516-2528, 2016.

2. Nedelcu RI, Ion DA, Holeab CA, Cioplea MD, Brînzea A and Zurac SA: Dendritic cells in melanoma - immunohistochemical study and research trends. Rom J Morphol Embryol 56: 997-1002, 2015.

3. West HC and Bennett CL: Redefining the role of langerhans cells as immune regulators within the skin. Front Immunol 8: 1941, 2018.

4. Serafim A, Petre DG, Moraru L, Cioflan HE, Vasile E, Mastalier-Manolescu B, Petrutescu M and Stancu IC: Gelatin-PVP hydrogels with potential skin grafts applications. Key Eng Mater 638: 38-46, 2015.

5. Deckers J, Hammad H and Hoste E: Langerhans cells: Sensing the environment in health and disease. Front Immunol 9: 93, 2018.

6. Nichita L, Zurac S, Popp C, Micu G, Bastian A, Stăniceanu F and Streinu-Cercel A: Dendritic cells - immunodeficiency virus (HIV): Early interactions. Rom J Intern Med 49: 251-255, 2011.

7. Malissen B, Tamoutounour S and Henri S: The origins and functions of dendritic cells and macrophages in the skin. Nat Rev Immunol 14: 417-428, 2014.

8. Boda D: Cellomics as integrative omics for cancer. Curr Proteomics 10: 237-245, 2013.
9. Petre M,Zurac S, Andrei R, Tebeica T, Birceanu A, Chirculescu R, Popp C, Evsei A, Staniceanu F and Bastian A: Langerhans cells distributions may discriminate early stage mycosis fungoides and inflammatory dermatoses. Virchows Arch 463: 101-352: 277, 2013.

10. Tebeică T, Andrei R, Zurac S and Stăniceanu F: Practical aspects regarding the histopathological diagnosis of early mycosis fungoides. Rom J Intern Med 54: 3-10, 2016.

11. Zurac S, Neagu M, Constantin C, Cioplea M, Nedelcu R, Bastian A, Popp C, Nichita L, Andrei R, Tebeica T, et al: Variations in the expression of TIMP1, TIMP2 and TIMP3 in cutaneous melanoma with regression and their possible function as prognostic predictors. Oncol Lett 11: 3354-3360, 2016.

12. Neagu M, Constantin C, Dumitrascu GR, Lupu AR, Caruntu C, Boda D and Zurac S: Inflammation markers in cutaneous melanoma - edgy biomarkers for prognosis. Discoveries (Craiova) 3: e38, 2015.

13. Zaba LC, Fuentes-Duculan J, Eungdamrong NJ, Abello MV, Novitskaya I, Pierson KC, Gonzalez J, Krueger JG and Lowe NA: Psoriasis is characterized by accumulation of immunostimulatory and Th1/Th17 cell-polarizing myeloid dendritic cells. J Invest Dermatol 129: 79-88, 2008.

14. Lowes MA, Chamian F, Abello MV, Fuentes-Duculan J, Lin SL, Nussbaum R, Novitskaya I, Carbonaro H, Cardinale I, Kikuchi T, et al: Increase in TNF-alpha and inducible nitric oxide synthase-expressing dendritic cells in psoriasis and reduction with efalizumab (anti-CD11a). Proc Natl Acad Sci USA 102: 19057-19062, 2005.

15. Căruntu C, Boda D, Căruntu A, Rotaru M, Baderca F and Zurac S: In vivo imaging techniques for psoriatic lesions. Rom J Morphol Embryol 55 (Suppl 3): 1191-1196, 2014.

16. Farkas L, Beiske K, Lund-Johansen F, Brandtzaeg $P$ and Jahnsen FL: Plasmacytoid dendritic cells (natural interferon-alpha/beta-producing cells) accumulate in cutaneous lupus erythematosus lesions. Am J Pathol 159: 237-243, 2001.

17. Blanco P, Palucka AK, Gill M, Pascual V and Banchereau J: Induction of dendritic cell differentiation by IFN- $\alpha$ in systemic lupus erythematosus. Science 294: 1540-1543, 2001.

18. Vermi W, Lonardi S, Morassi M, Rossini C, Tardanico R, Venturini M, Sala R, Tincani A, Poliani PL, Calzavara-Pinton PG, et al: Cutaneous distribution of plasmacytoid dendritic cells in lupus erythematosus. Selective tropism at the site of epithelial apoptotic damage. Immunobiology 214: 877-886, 2009.

19. Phung TI, Wright TS, Pourciau KY and Smoller BR: Spongiotic dermatitis. Pediatr Dermatol: Jun 21, 2017 (Epub ahead of print). doi: 10.1007/978-3-319-44824-4_1.

20. Colmenero I, Torrelo A and Reyes-Múgica M: Skin. In: Essentials of Surgical Pediatric Pathology. Cohen MC and Scheimberg I (eds).Cambridge University Press, Cambridge, pp1-2, 2014.

21. Abreu Velez AM, Loebel AM and Howard MS: Spongiotic dermatitis with a mixed inflammatory infiltrate of lymphocytes, antigen presenting cells, immunoglobulins and complement. Dermatol Online 2: 52-57, 2011.

22. Deguchi $M$, Aiba S, Ohtani $H$, Nagura $H$ and Tagami $H$ : Comparison of the distribution and numbers of antigen-presenting cells among T-lymphocyte-mediated dermatoses: $\mathrm{CDla}^{+}$, factor $\mathrm{XIIIa}^{+}$, and $\mathrm{CD}^{6} 8^{+}$cells in eczematous dermatitis, psoriasis, lichen planus and graft-versus-host disease. Arch Dermatol Res 294: 297-302, 2002.

23. Lin TC, Wu PY, Lin TY, Yeh SP, Chen SC and Lee TL: Langerhans cell hyperplasia in the tumor stage of mycosis fungoides: A mimic of Langerhans cell histiocytosis. Dermatol Sin 29: 101-105, 2011.

24. Goteri G, Filosa A, Mannello B, Stramazzotti D, Rupoli S, Leoni P and Fabris G: Density of neoplastic lymphoid infiltrate, $\mathrm{CD}^{+} \mathrm{T}$ cells, and $\mathrm{CD} 1 \mathrm{a}^{+}$dendritic cells in mycosis fungoides. J Clin Pathol 56: 453-458, 2003.

25. Berger CL, Hanlon D, Kanada D, Dhodapkar M, Lombillo V, Wang N, Christensen I, Howe G, Crouch J, El-Fishawy P, et al: The growth of cutaneous T-cell lymphoma is stimulated by immature dendritic cells. Blood 99: 2929-2939, 2002.

26. Ion A, Popa IM, Laura ML, Lisievici C, Lupu M, Voiculescu V, Caruntu C and Boda D: Proteomic approaches to biomarker discovery in cutaneous T-cell lymphoma. Dis Markers 2016: 9602472, 2016.

27. Ni X and Duvic M: Dendritic cells and cutaneous T-cell lymphomas. G Ital Dermatol Venereol 146: 103-113, 2011.

This work is licensed under a Creative Commons Attribution-NonCommercial-NoDerivatives 4.0 International (CC BY-NC-ND 4.0) License. 